\title{
Geology, Petrology and Geochemistry of Volcanic Rocks Around Arba Minch, Southern Ethiopia
}

\author{
Gosaye Berhanu \\ Department of Geology, Arba Minch University, Arba Minch, Ethiopia \\ Email address: \\ gossangeol2010@gmail.com \\ To cite this article: \\ Gosaye Berhanu. Geology, Petrology and Geochemistry of Volcanic Rocks Around Arba Minch, Southern Ethiopia. Earth Sciences. \\ Vol. 8, No. 3, 2019, pp. 160-168. doi: 10.11648/j.earth.20190803.14
}

Received: April 24, 2019; Accepted: May 28, 2019; Published: June 12, 2019

\begin{abstract}
The study area is subpart of the southern main Ethiopian Rift and geographically bounded between UTM (Universal Transverse Mercator) coordinates of $662000 \mathrm{~m}-669000 \mathrm{~m}$ latitude and $336000 \mathrm{~m}-341000 \mathrm{~m}$ longitude. The main aim of this study is to investigate the geological, petrographic and geochemical properties of volcanic rocks around Arba Minch, southern Ethiopia. Both field and laboratory analytical techniques are employed to characterize minerals and the rock types. Eight thin section samples are prepared to study petrographic properties of minerals and five best representative samples are analyzed for whole rock chemistry using ICP-MS (Inductively Coupled Plasma-Mass Spectrometry). Petrographically, samples from the porphyritic basalt show phenocrysts of olivine and plagioclase within the fine-grained groundmass. There are rounded to subrounded holes or vesicles that appear white under plane polarized light observations and dark under cross polarized light observations which further confirms vesicular nature of the basalt. Thin section sample from rhyolite outcrop shows phenocrysts of K-feldspar and quartz within tiny fine-grained groundmass of feldspar minerals. Aphanitic basalt, Porphyritic basalt, vesicular basalt, rhyolite and dolerite are the rock units found in the study area. The geochemical results of the analyzed samples indicate silica ranges of (48.5-60.1)\%. Based geochemical classifications made, rock units are classified into rhyolite, basalt, hawaiite and mugherite rock types. Trace element analytical results show all samples lie on the within plate tectonic setting. The rare earth and trace element ratios and spider diagrams confirmed that most samples are derived from magmas of asthenospheric source with little crustal contamination.
\end{abstract}

Keywords: Rift, Rock, Mineral, Basalt, Element

\section{Introduction}

The East African Rift (EARS) is an active continental rift zone in eastern Africa that appears to be a developing divergent tectonic plate boundary where rift tectonics accompanied by intense volcanism has taken place from the Tertiary to Recent. Within the EARS, the Main Ethiopian Rift represents the link region between the Afar triple junction and the Kenya Rift regions where extensional deformation nucleated as early as late Oligocene-early Miocene times [2, 6, 8, 11]. Volcanic rocks of Pliocene and Pleistocene age such as pantelleritic rhyolites, trachytes and ignimbrites are abundant within the rift floor and on the adjoining plateau [9].

Magmatic activity in East Africa began in the Eocene and recent reviews suggest multiple pulses of magmatism since $\sim 45 \mathrm{Ma}$, with the most volumetrically-significant flood basalt and silicic eruptions taking place in the Oligocene $\sim 33.9$ to $27 \mathrm{Ma}$ as cited in a study [17].

The study area is located at the western margin of NNESSW trending southern domain of main Ethiopian rift belonging to the East African Rift system. Different authors and researchers have written documents at various scales about the Geology of Arba Minch area, southern Ethiopia. The northern part of Lake Abaya, the extensional axis of the MER became the locus of volcanic activity with bimodal basalt - rhyolite extrusion in the rift floor during Quaternary period [16].

Irrespective of these works, detailed geological and geochemical investigations of volcanic rocks is not conducted yet. Therefore, this research studies the geological, petrographic and geochemical properties of volcanic rocks around Arba Minch, Southern Ethiopia. 


\section{Description of the Study Area}

The study area is subpart of the East African Rift system which lies at the southern margin of the main Ethiopian Rift. The area is geographically bounded between UTM coordinates of $662000 \mathrm{~m}-669000 \mathrm{~m}$ latitude and $336000 \mathrm{~m}$ $341000 \mathrm{~m}$ longitude. It lies at the eastern and western sides of Arba Minch city (Figure 1). The physiography of the study area is a result of volcanism, tectonic effect and erosion processes which resulted in the formation of rugged topographies with steep valleys and high ridges. The climate of the study area is characterized by arid climatic condition with high temperature ranges. It can be characterized by two rainy seasons that is in autumn and spring. In winter, there is much less rainfall in Arba Minch than in summer.

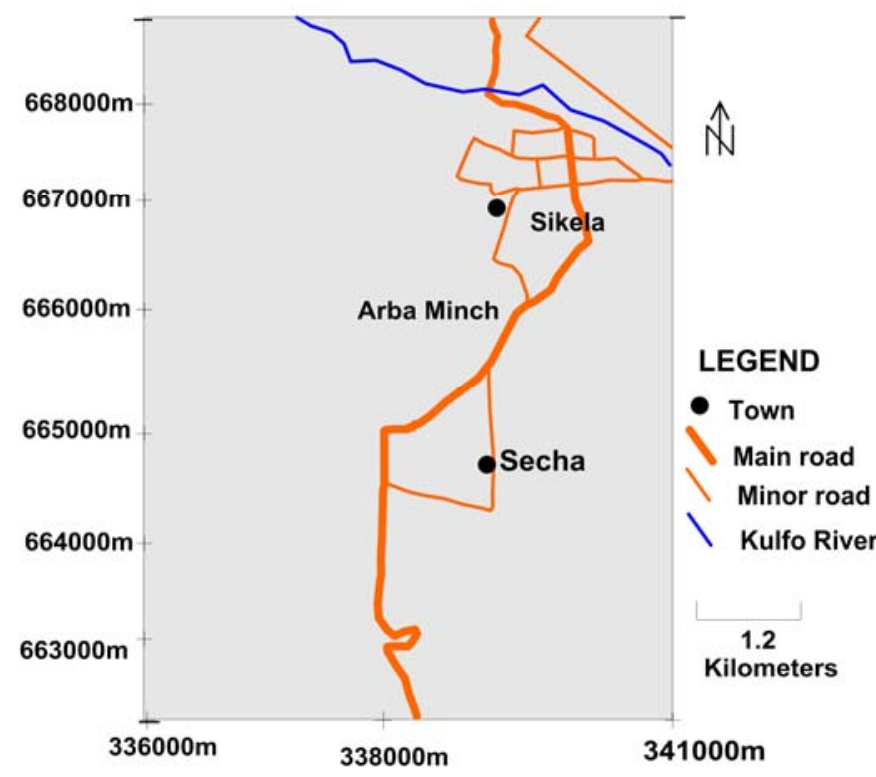

Figure 1. Location of the study area.

\section{Methodologies}

Different sets of methodologies were employed to achieve the objective of this research work. The methodology adopted for data acquisition, analysis, processing and the procedures followed while planning and carrying out the geological, petrographic and geochemical investigations are described as follows.

\subsection{Pre-Field Activities}

The first phase of this research study gave emphasis on collection and review of different related journals and reports which are done by different companies and researchers.

\subsection{Field Mapping and Sampling}

Detail description of different outcrops was done based on the lithological and mineralogical variations. A total of fourteen samples are collected during the field work and among them eight best representative samples are selected for thin section and whole rock geochemical analysis.

\subsection{Post Field Activities: Sample Preparation and Analysis}

\subsubsection{Sample Preparation for Thin Section}

Eight selected samples were resized or reduced by hammer in Arba Minch University Geological laboratory and were further resized by using cutting machine. First the rock samples were cut and trimmed into rectangular slab and further cutting was then followed till it reduced to the required size to be polished by DAP-U polishing machine, not greater than $4 \mathrm{~cm}$ since the mould has a maximum diameter of $4 \mathrm{~cm}$. The rock samples were cut-off and ground mechanically to transparent thickness using carbide abrasive until the slice reaches the conventional thickness of 30 microns. This is carried out using petro discs with 400-grit aluminum oxide powder. Eight (8) thin sections were prepared at Geological Survey of Ethiopia (GSE), Addis Ababa central Laboratory.

\subsubsection{Sample Preparation for Geochemical Analysis}

Five selected samples were resized and crushed to rock powder with crushing machine at Addis Ababa to be sent to Ireland for analysis. Inductively Coupled Plasma Mass Spectrometry is the analytical instrument used for geochemical analysis. Major, minor and trace elements analytical results for five rock samples are received from ALS (Australian Laboratory Services) center from Ireland (Table 1).

\subsubsection{Data Processing}

Mineralogical properties of rocks are identified from petrographic studies of thin section samples. The analytical results of major, minor and trace elements were used to study the geochemical nature of volcanic rocks of the area. Field based naming of the rock types are further proven from petrographic studies and geochemical classifications made by using Geochemical Data Toolkit (GCDkit) software. Different plots of major, minor and trace elements were used in petrological interpretations. Tectonic setting of the study area is distinguished by using $\mathrm{Zr}-\mathrm{Ti}$ [13] and $\mathrm{Zr}-\mathrm{Zr} / \mathrm{Y}$ [14] plots. The rare earth and trace element spider plots and ratios are used for studying the petrogenesis of the rock units.

\section{Result}

\subsection{Geology and Petrography}

The study area is covered by volcanic rocks such as aphanitic basalt, porphyritic basalt, vesicular basalt, rhyolite and dolerite and an alluvial deposit.

\subsubsection{Aphanitic Basalt}

It is a fine-grained extrusive igneous rock characterized by highly packed crystals and dominantly contains black colored minerals with some visible quartz grains (Figure 2a). It is formed on the earth's surface under faster rate of cooling from the basic lava. Small irregular oreinted fractures has affected the rock unit on most part of the exposures (Figure 2b). The fine-grained basalt shows small elongated plagioclase feldspar using a hand lense. 

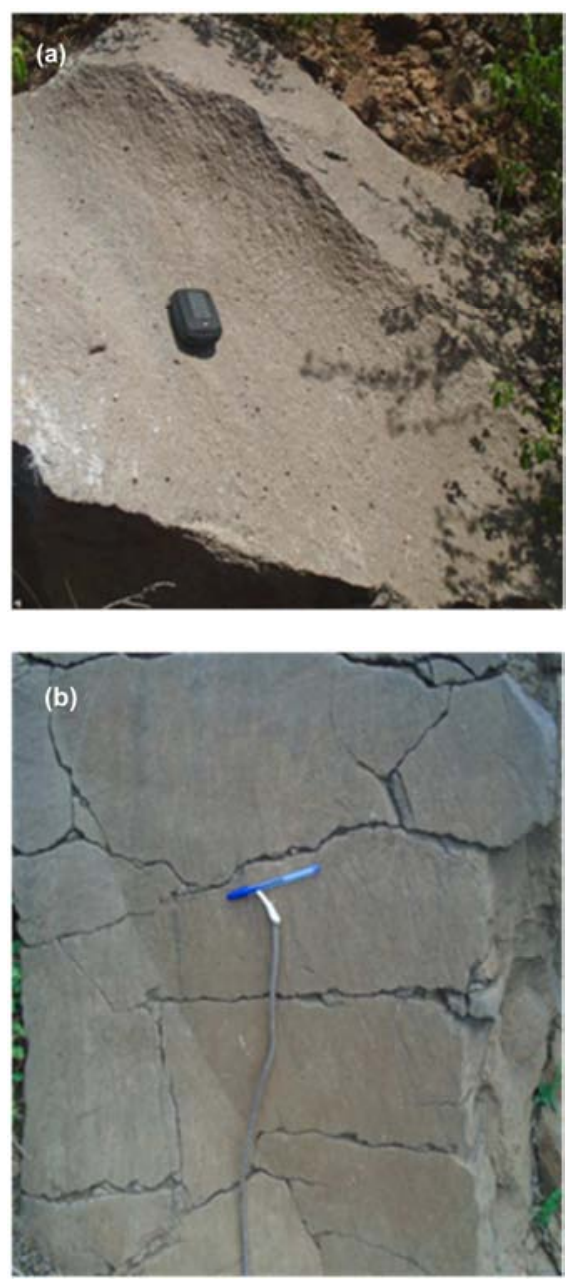

Figure 2. (a) Aphanitic basalt wich shows grains of plagiocalse feldspar and minor quartz grains (b) Irregular fractures on basalt outcrop.

Petrographically, the thin section sample shows dominant distribution of microphenocrysts of plagioclase feldspar (Figure 3). Small amount of opaque minerals that remains dark under both plane and cross polarized light observations are found associated together with plagioclase feldspar. This unit has intergranular texture in which glassy and opaque minerals distributed between the plagioclase grains. The mineral forming this rock unit has subhedral to euhedral shape. Fine- grained olivine minerals are changed to epidote.
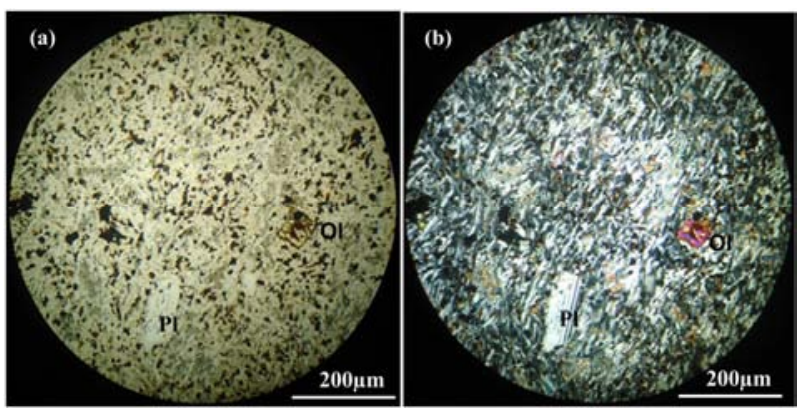

Figure 3. Thin section photo showing microphenocryts of plagioclase feldspar and olivine in aphanitic basalt under (a) plane polarized light and (b) cross polarized light observations. $(\mathrm{Ol}=$ olivine and $\mathrm{Pl}=$ plagioclase $)$.

\subsubsection{Porphyritic Basalt}

Relatively large crystals of plagioclase feldspar and olivine are clearly visible within the fine-grained groundmass. Besides to these major minerals, minor amounts of quartz and secondary calcite minerals are also observed (Figure 4).

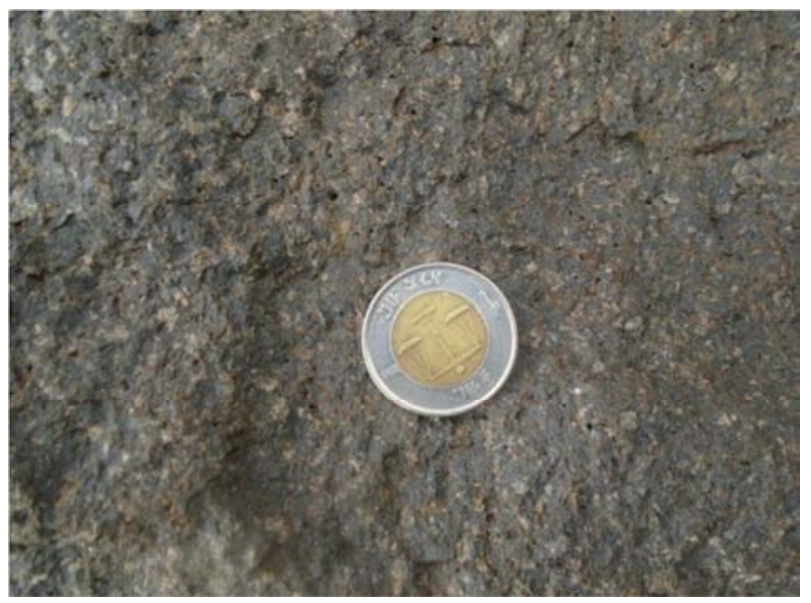

Figure 4. Photograph taken from the outcrop of porphyritic basalt.

The phenocrysts of plagioclase feldspar has developed concentric zoning where the outer rim shows a number of bandings. The inner core encloses small crystals of other minerals. The fine- grained groundmass is dominated by tiny laths of plagioclase and pyroxene minerals. The photomicrograph (Figure 5a) took in plane polarized light shows a number of phenocrysts of plagioclase feldspar and olivine. Under cross polarized observations, the large crystals of plagioclase feldspar shows concentric zoning (Figure $5 b$ ). The phenocrysts of plagioclase feldspar also developed lamellar twining. Olivine phenocryst shows little irregular cracks and along the margins alterations are apparently visible. Green minerals of epidote which has low relief are results of alterations of olivine mineral.

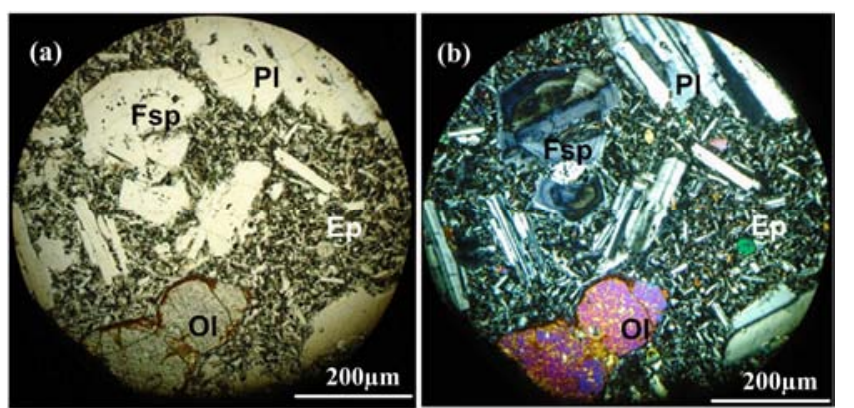

Figure 5. Phenocrysts of olivine and plagioclase under (a) plane polarized and (c) cross polarized light observations. $(\mathrm{Ol}=$ Olivine and $\mathrm{Pl}=$ Plagiocalse).

\subsubsection{Vesicular Basalt}

This rock unit is characterized by open spaces called vesicles. It is fine-grained, has black to grey color. The rock unit has significant porosity due to escaping of gas bubbles during rapid cooling of the magma. 


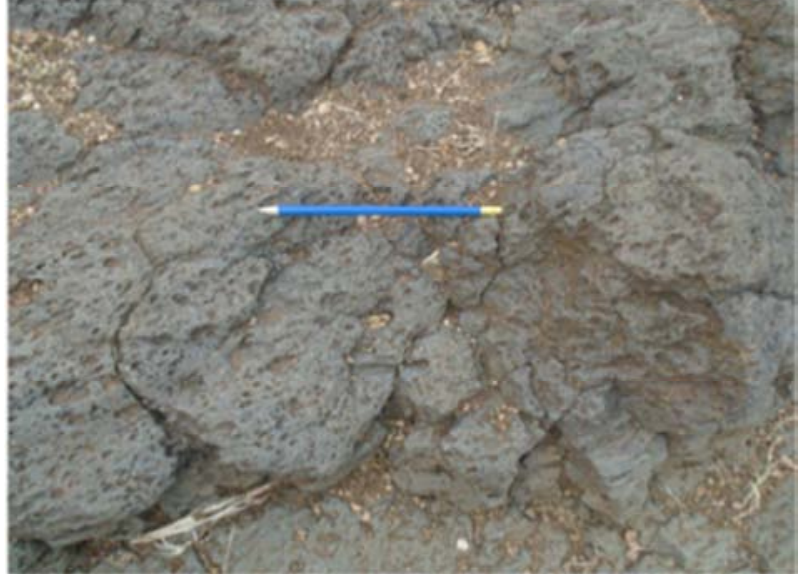

Figure 6. A photograph showing outcrop of vesicular basalt.

The thin section sample indicates rounded to sub rounded holes or vesicles which appears white under plane polarized observations and dark under cross polarized observations. Phenocrysts of pyroxene minerals are observed within the fine-grained groundmass laths of plagioclase feldspar. Olivine show euhedral form, irregular fractures, higher relief and bright interference color. Microphenocryts of opaque minerals which appear dark under both plane and cross polarized light observations are observed.
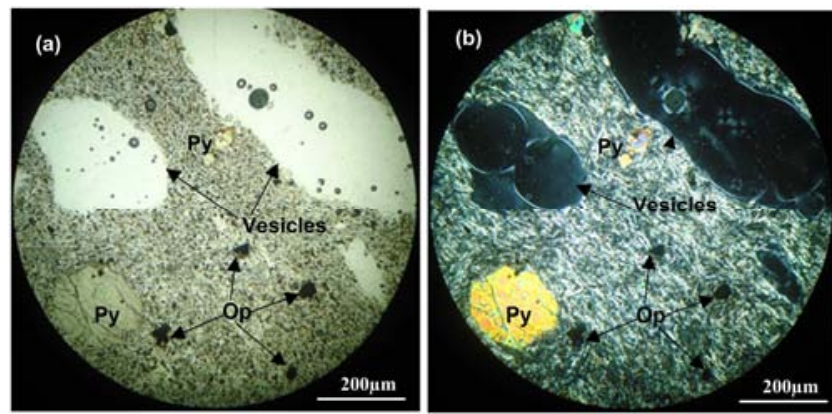

Figure 7. Photomicrograph indicating euhedral pyroxene minerals, opaque and vesicles under (a) plane polarized and (b) cross polarized observations. $(P y=$ Pyroxene and $O p=O p a q u e)$.

\subsubsection{Rhyolite}

The lithology has fine-grained texture and formed due to rapid cooling of acidic lavas. It is characterized by flow banding and leucocratic color (Figure 8a). It formed a ridge and steep sided cone may be due to high viscosity (Figure $8 b)$.

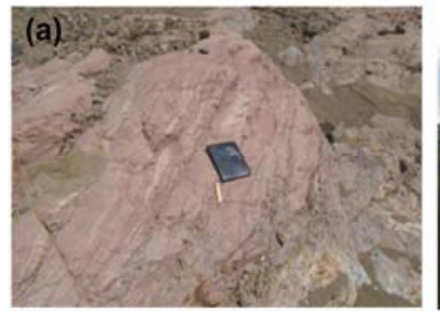

(b)

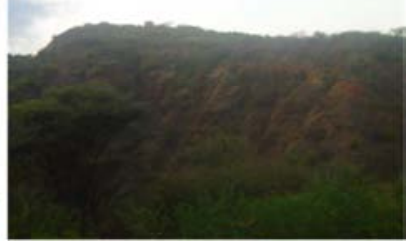

Figure 8. (a) Flow banding structure and (b) ridges of rhyolite.

Under thin section, this rock unit consists of phenocrysts of K-feldspar within the fine-grained ground mass. The sample shows porphyritic fluidal texture and contains quartz and tiny plagioclase. It contains phenocrysts of feldspar and quartz in euhedral forms in a groundmass which is glassy but is full of tiny laths of alkali feldspar.
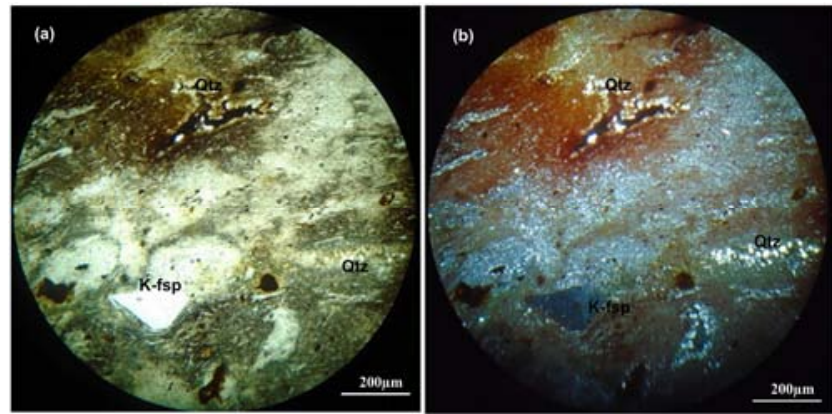

Figure 9. Phenocrysts of K-feldspar and quartz with fluidal texture under (a) plane polarized light observation and (b) cross polarized light observation.

\subsubsection{Dolerite}

This rock unit has dark grey color with small specks of white and also it has medium grain size. This sub intrusive crystalline igneous rock has typical spheroidal weathering (exfoliation weathering) which is the splitting of rocks into a series of concentric shells by subsequent weathering processes. Much of the dolerite found in these places has a greenish tinge because of the presence of the mineral olivine.

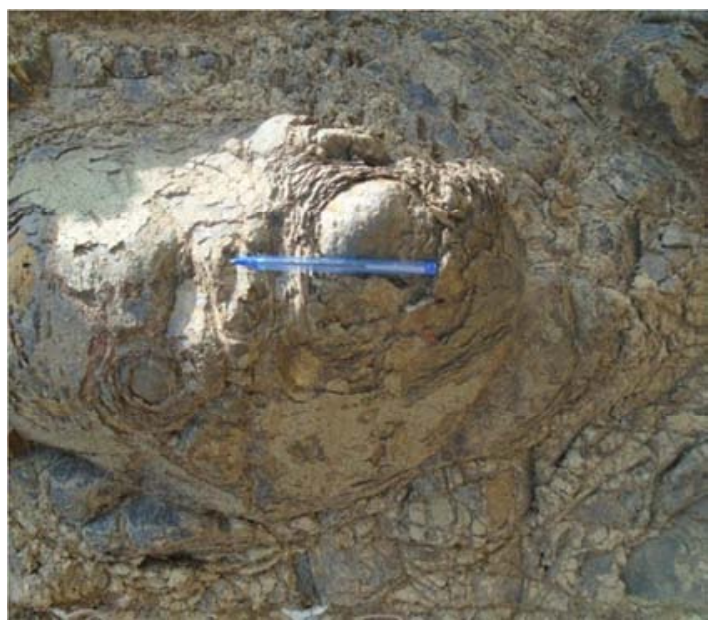

Figure 10. Dolerite rock unit with distinctive exfoliation weathering.
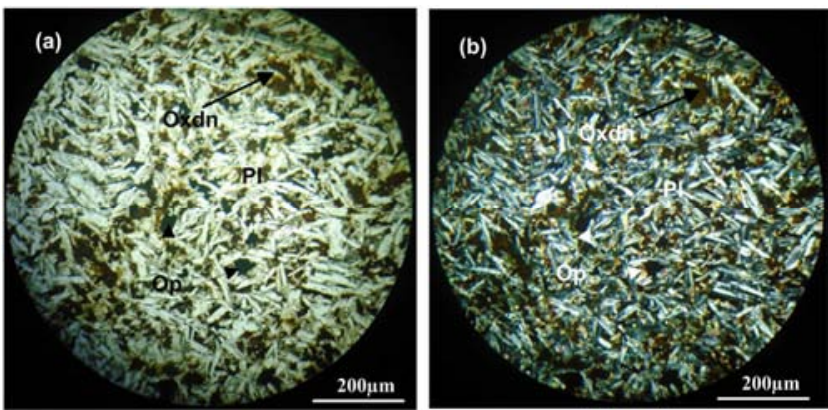

Figure 11. Opaque minerals are changing to reddish color due to oxidation and microphenocryts of plagioclase feldspars are common both under (a) plane and (b) cross polarized light observations. 
Petrographically, the shape of most of the minerals is subhedral. Plagioclase feldspar is the only major mineral in the thin section. This plagioclase feldspar shows polysynthetic twinning under XPL. Also plagioclase feldspar is found as phenocryst surrounded by the other fine-grained minerals and this phenocryst form of plagioclase feldspar shows contact/simple twinning under XPL. The given thin section of the rock contains other minor minerals such as biotite and accessory minerals such as iron oxides and opaque. Finegrained groundmass of feldspar aligned sub parallel along their flow directions. Phenocrysts of alkali feldspars Oxidations of iron ores may be hematite or magnetite minerals.

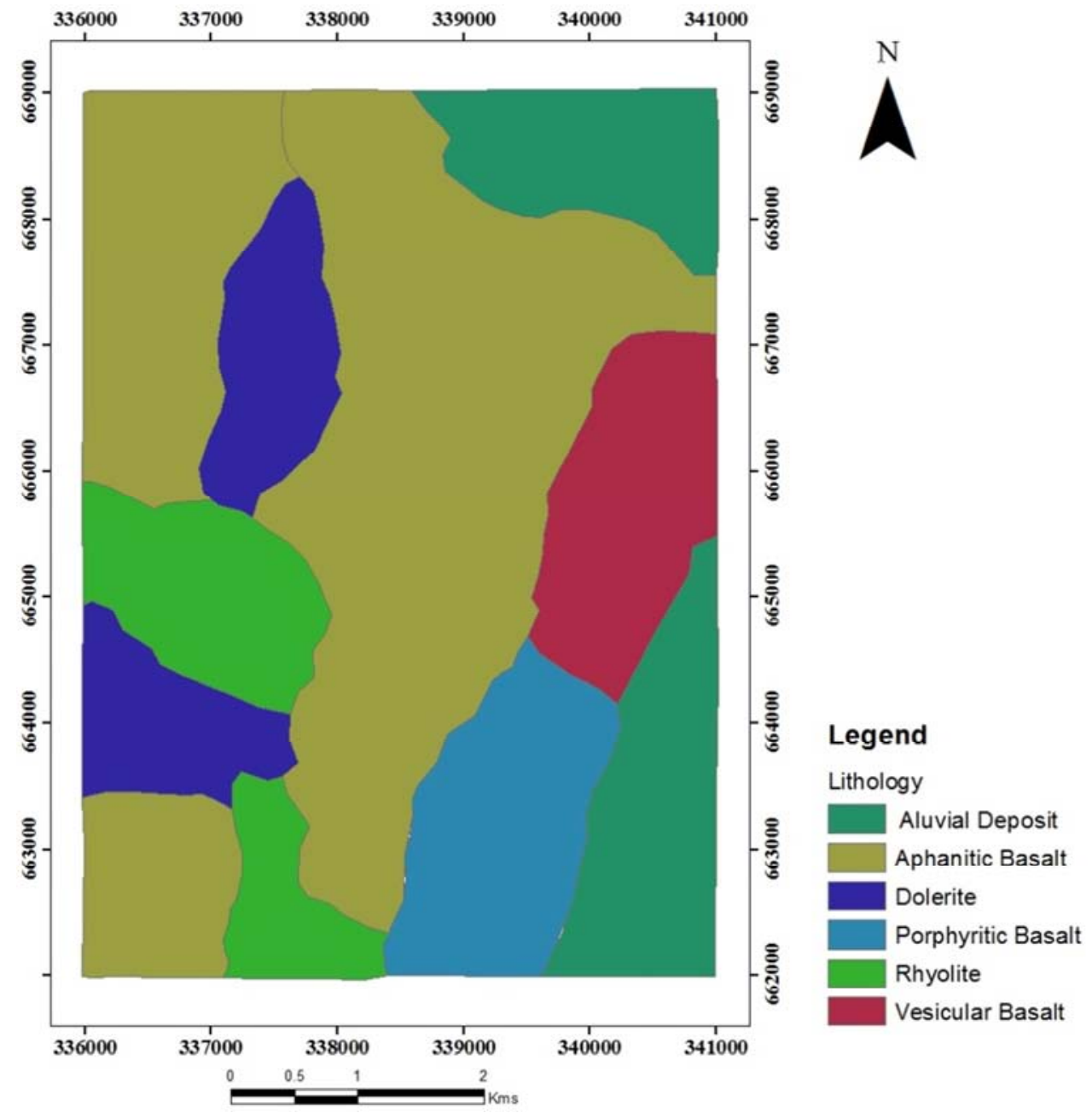

Figure 12. Geological map of the study area.

\subsection{Geochemical Result}

Table 1. Major, trace and rare earth elements analytical results.

\begin{tabular}{|c|c|c|c|c|c|}
\hline Major and trace oxides in \% & T1-S1 & T1-S2 & T1-S3 & T2-S1 & T3-S2 \\
\hline $\mathrm{SiO}_{2}$ & 52.5 & 49.8 & 67.1 & 48.5 & 51.8 \\
\hline $\mathrm{Al}_{2} \mathrm{O}_{3}$ & 17.65 & 18.15 & 14.75 & 13.45 & 16.7 \\
\hline $\mathrm{Fe}_{2} \mathrm{O}_{3}$ & 8.32 & 9.42 & 5.62 & 14.1 & 10.45 \\
\hline $\mathrm{MgO}$ & 2.58 & 3.85 & 0.22 & 4.2 & 2.67 \\
\hline $\mathrm{Na}_{2} \mathrm{O}$ & 4.49 & 4.35 & 3.17 & 3.09 & 4.6 \\
\hline $\mathrm{K}_{2} \mathrm{O}$ & 2.99 & 2.23 & 5.61 & 1.11 & 2.73 \\
\hline $\mathrm{TiO}_{2}$ & 1.72 & 1.86 & 0.5 & 2.71 & 2.31 \\
\hline $\mathrm{MnO}$ & 0.17 & 0.16 & 0.02 & 0.2 & 0.2 \\
\hline $\mathrm{P}_{2} \mathrm{O}_{5}$ & 0.62 & 0.59 & 0.13 & 0.45 & 0.9 \\
\hline $\mathrm{SrO}$ & 0.06 & 0.08 & 0.01 & 0.03 & 0.06 \\
\hline $\mathrm{BaO}$ & 0.13 & 0.09 & 0.06 & 0.05 & 0.12 \\
\hline LOI & 2.03 & 0.3 & 2.3 & 2.96 & 1 \\
\hline Sum & 99.1 & 98.97 & 100 & 98.65 & 99.62 \\
\hline Trace elements in ppm & T1-S1 & $\mathrm{T} 1-\mathrm{S} 2$ & T1-S3 & $\mathrm{T} 2-\mathrm{S} 1$ & $\mathrm{~T} 3-\mathrm{S} 2$ \\
\hline
\end{tabular}




\begin{tabular}{llllll}
\hline Major and trace oxides in \% & T1-S1 & T1-S2 & T1-S3 & T2-S1 & T3-S2 \\
\hline $\mathrm{Sr}$ & 716 & 823 & 195 & 405 & 631 \\
$\mathrm{Zr}$ & 257 & 224 & 1165 & 218 & 272 \\
$\mathrm{~V}$ & 111 & 192 & 11 & 336 & 156 \\
$\mathrm{Y}$ & 30.9 & 25.1 & 70.8 & 38.4 & 37.8 \\
$\mathrm{Ba}$ & 1155 & 814 & 608 & 469 & 1040 \\
$\mathrm{Ce}$ & 133 & 102 & 180.5 & 53.7 & 128.5 \\
$\mathrm{Cr}$ & 10 & 50 & $<10$ & 10 & $<10$ \\
$\mathrm{Cs}$ & 0.49 & 0.49 & 0.16 & 0.04 & 0.52 \\
$\mathrm{Dy}$ & 5.91 & 4.68 & 12.85 & 6.76 & 6.94 \\
$\mathrm{Er}$ & 3.21 & 2.43 & 7.78 & 4.07 & 3.94 \\
$\mathrm{Eu}$ & 2.22 & 2.03 & 3.26 & 2.16 & 2.94 \\
$\mathrm{Ga}$ & 22.6 & 21.6 & 31.2 & 24.9 & 22.7 \\
$\mathrm{Gd}$ & 6.52 & 5.99 & 13.8 & 7.38 & 8.72 \\
$\mathrm{Hf}$ & 5.5 & 4.7 & 23 & 5.3 & 6.1 \\
$\mathrm{Ho}$ & 1.11 & 0.89 & 2.58 & 1.43 & 1.33 \\
$\mathrm{La}$ & 77 & 58.1 & 101 & 22.7 & 71.8 \\
$\mathrm{Lu}$ & 0.44 & 0.36 & 1.3 & 0.48 & 0.54 \\
$\mathrm{Nb}$ & 108.5 & 91.3 & 78.6 & 13.2 & 109 \\
$\mathrm{Nd}$ & 48.2 & 39.3 & 92.7 & 32.5 & 58 \\
$\mathrm{Pr}$ & 13 & 11.2 & 22.3 & 6.79 & 15.05 \\
$\mathrm{Rb}$ & 90.9 & 65.5 & 96.7 & 12.5 & 74.3 \\
$\mathrm{Yb}$ & 3.19 & 2.37 & 7.96 & 3.57 & 3.53 \\
$\mathrm{Eu} / \mathrm{Eu} *$ & 0.88 & 0.94 & 0.61 & 0.86 & 0.96 \\
$\mathrm{La} / \mathrm{Ta}$ & 12.22 & 11.39 & 23.49 & 28.38 & 11.97 \\
$\mathrm{La} / \mathrm{Nb}$ & 0.71 & 0.64 & 1.28 & 1.72 & $<0$ \\
$\mathrm{Ti} / \mathrm{Yb}$ & 0.01 & $<0.0073$ & 0.00 & $<0.0056$ & $<0057$ \\
\hline
\end{tabular}

\subsubsection{Characteristics of Major and Minor Oxides}

The analyzed samples from the different volcanic rocks display different ranges in their major and minor oxides. The analysed five samples have percentage values silica ranging from (48.5-60.1)\%, aluminum oxide (13.45-18.15), iron oxide (5.62-14.1), calcium oxide $(0.52-8.08)$, sodium oxide (3.09-4.6), magnesium oxide $(0.22-4.2)$, potasium oxide (1.11-5.61), chromium oxide (0.002-0.009), titanium oxide $(0.5-2.71)$, manganese oxide $(0.02-0.2)$, phosporous oxide (0.13-0.9), strontium oxide $(0.03-0.08)$ and barium oxide (0.05-0.13).

\subsubsection{Trace and Rare Earth Elements Geochemistry}

The analyzed samples from different volcanic suites exhibited different trace and rare earth element contents. Samples have trace and rare earth element contents of (195823) ppm of Sr, (218-1165) ppm of Zr, (11-336) ppm of V, (25.1-70.8) ppm of Y, (469-1155) ppm of Ba, (53.7-180.5) ppm of Ce, (10-50) ppm of Cr, (0.04-0.52) ppm of Cs, (2.437.78) ppm of Er, (2.03-3.26) ppm of Eu, (21.6-31.2) ppm of $\mathrm{Ga},(5.99-13.8) \mathrm{ppm}$ of $\mathrm{Gd},(4.7-23) \mathrm{ppm}$ of $\mathrm{Hf},(0.89-2.58)$ ppm of Ho, (22.7-101) ppm of La, (0.36-1.3) ppm of Lu, (13.2-109) ppm of $\mathrm{Nb},(32.5-92.7) \mathrm{ppm}$ of Nd, (6.79-22.3) ppm of Pr, (12.5-96.7) ppm of $\mathrm{Rb}$ and (2.37-7.96) ppm of $\mathrm{Yb}$.

\subsubsection{Geochemical Classifications}

Different schemes of classifications were employed by petrologists for classifying various types of volcanic rocks. By utilizing the analyzed major, minor and trace elements data, a number of classification systems were conducted to identify compositional variations, tectonic settings and etc. Geochemical classification techniques such as TAS [4] and R1-R2 [5] are used to identify the chemical nature of rock samples.

I. R1-R2 classification

Based on the R1-R2 classifications same results are obtained where most of the samples are plotted on the basalt field and one sample lies on the alkali rhyolite field.

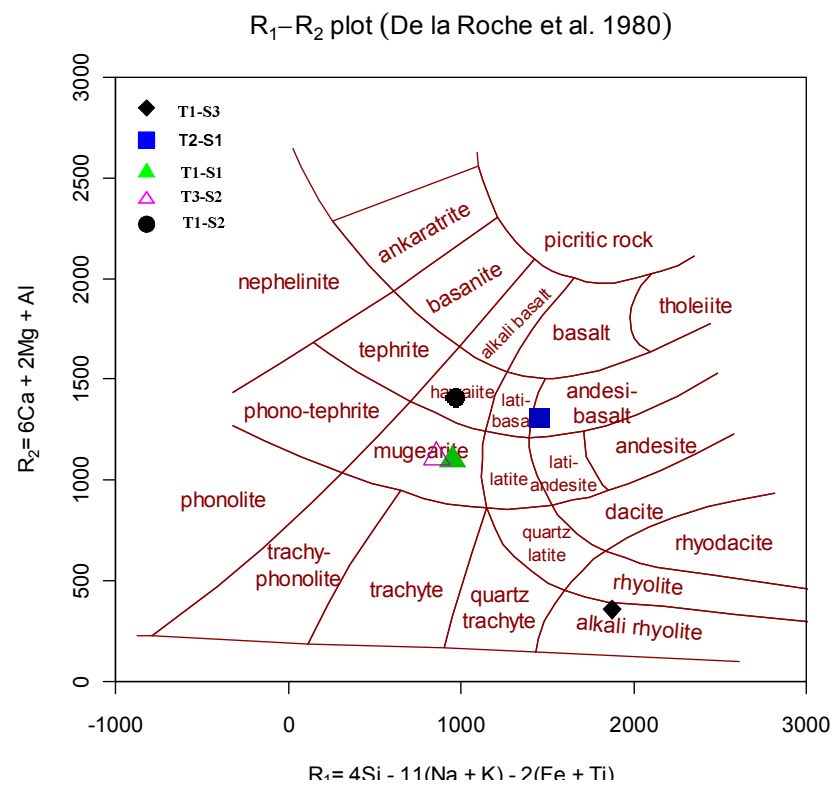

Figure 13. R1-R2 classification of volcanic rock [5].

\section{TAS classification}

Based on TAS classification, out of five samples four samples are classed under basic type of igneous rock while one sample (T1-S3) lies on the acidic Rhyolite field. T1-S1 and T3-S2 samples are plotted at Mugearite field (an alkaline basalt), Sample (T1-S2) plotted on Hawaiite (a type of alkali basalt) field while sample (T2-S1) is classed under the basalt field. 
TAS (Cox et al. 1979)

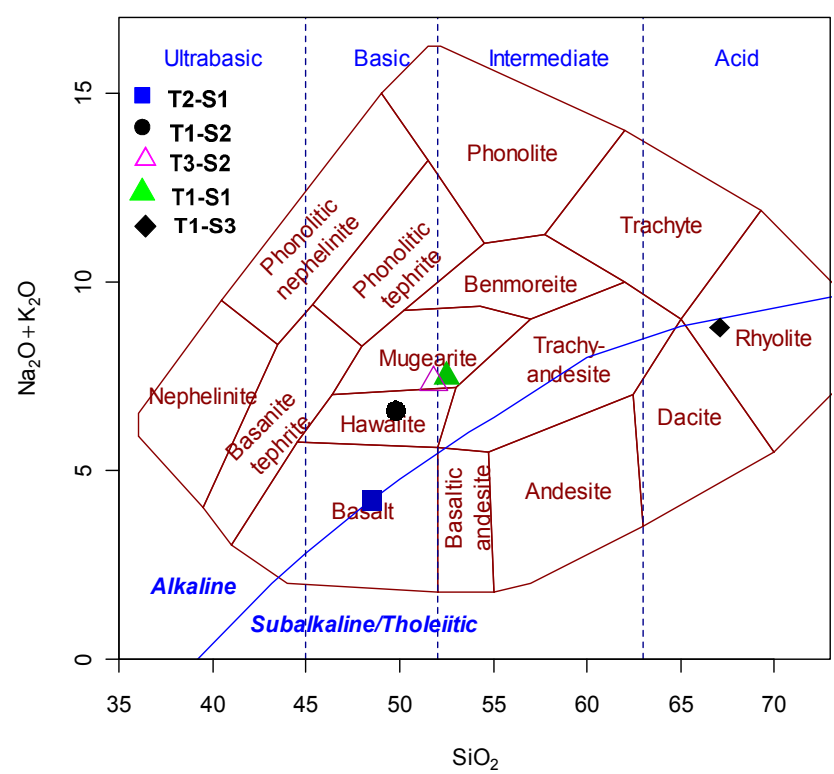

Figure 14. TAS classification [4].

\subsubsection{Tectonic Setting}

Trace elements data is used for the discrimination of tectonic settings.Based on the $\mathrm{Zr}$-Ti [13] plot of samples all lie on the with in plate tectonic settings.

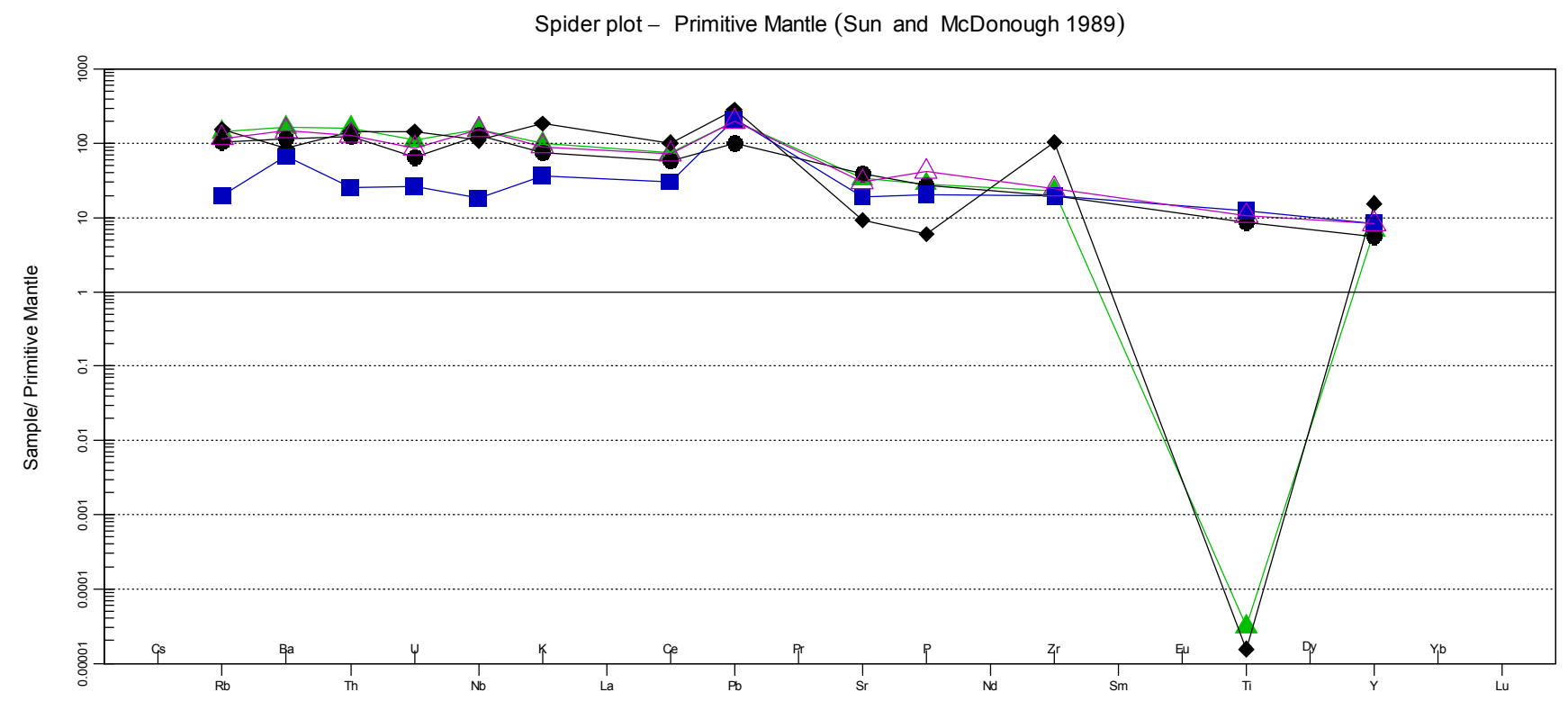

Figure 16. Trace elements spider diagrams based on the primitive mantle [15].

Where as the rare earth element spider diagram shows more than hundered fold enrichments in LREE and slight enrichement to depletions in HREEs.

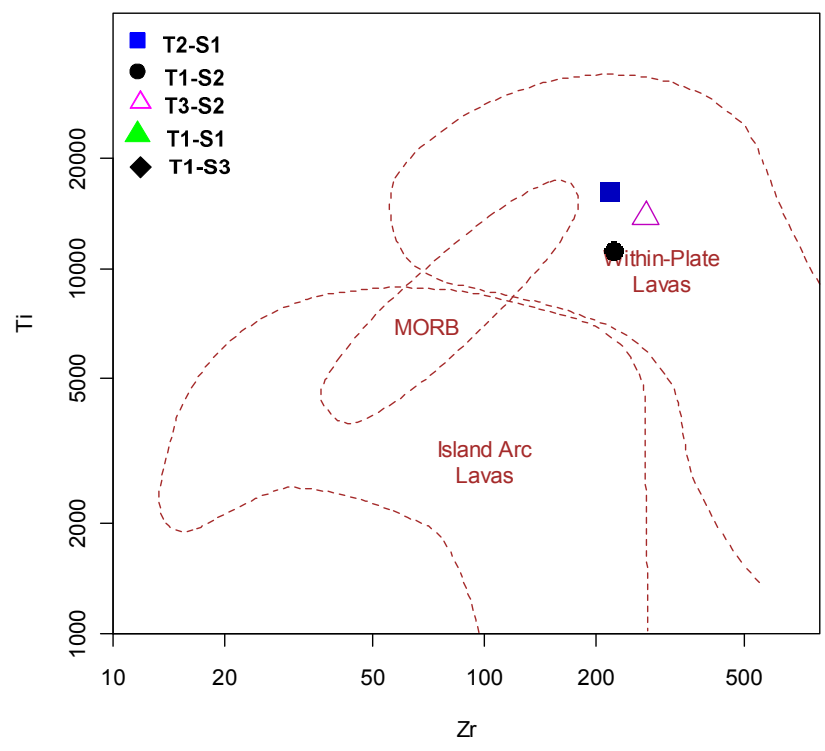

Figure 15. Tectonic discrimination by using Zr-Ti [13].

\subsubsection{Trace Rare Earth Elements Pattern}

The analysed samples are characterized with 10-100 fold enrichment of most large ion lithophile elements $(\mathrm{Rb}, \mathrm{Ba}, \mathrm{K}$ and $\mathrm{Pb}$ ) and high field strength elements, uranium and thorium while the other high field strength elements; Y, Zr, and Ti were relatively flat and show slight depletions under primitive mantle normalizations.
Spider plot - Primitive Mantle (Sun and McDonough 1989) 


\section{Spider plot - REE chondrite (Boynton 1984)}

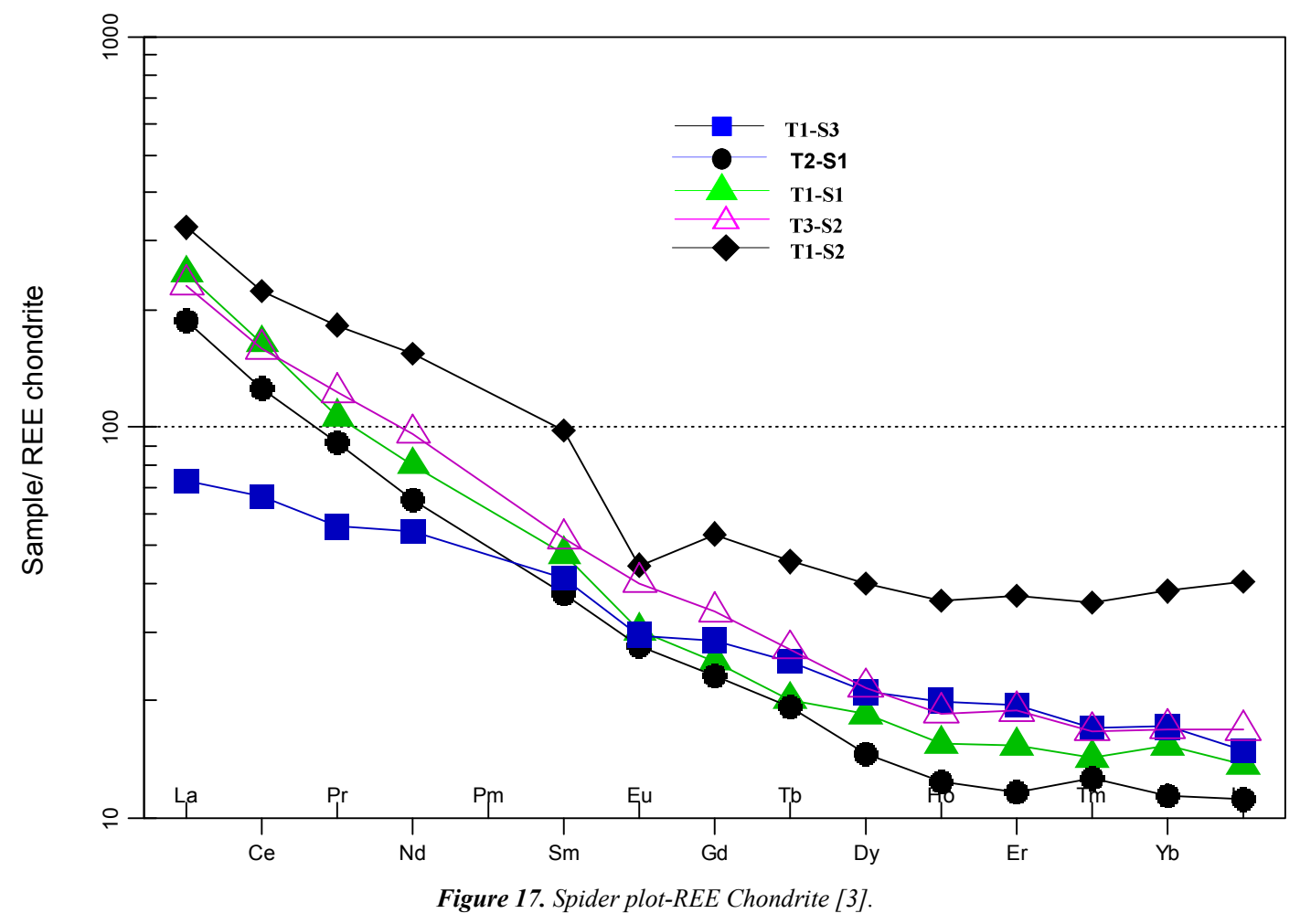

\section{Discussion}

Besides to the geological mapping data, petrographic and geochemical results confirmed that the study area is covered by rocks units such as aphanitic basalt, Porphyritic basalt, vesicular basalt, rhyolite and dolerite.

Petrographic studies revealed that the dominant minerals for most of the thin section samples are mafic in nature (olivine, pyroxene and plagioclase) except one sample taken from the rhyolite outcrop which consists of higher proportion of quartz and K-feldspar.

Based on the primitive mantle [15], trace elements spider diagrams show enrichment in LILE's (Large Ion Lithophile Elements) relative to the HFSE's (High Field Strength Elements) and this could be resulted from a low-degrees partial melting in mantle origin. Among all, sample T1-S3 (Rhyolite) and T1-S1 (porphyritic basalt) developed a maximum titanium negative anomaly that can be due to crustal contaminations.

$\mathrm{La} / \mathrm{Ta}$ ratios have been used as an indicator of crustal contamination [7, 10]. Leat PT.et al. [10] sugested that rocks with $\mathrm{La} / \mathrm{Ta}$ ratios of $<22$ are derived from an asthenospheric source and have undergone little to no contamination from the continental crust or mantle lithosphere. Out of the analysed five rock samples two samples, T1-S3 and T2-S1 shows $\mathrm{La} / \mathrm{Ta}$ ratios of greater than 22 which may indicate that rhyolite and dolerite rocks have been affected by crustal contaminations. As cited in [11], $\mathrm{La} / \mathrm{Nb}$ of $>1.5$ indicates crustal contamination. Likewise, $\mathrm{La} / \mathrm{Nb}$ ratios of the analysed rocks ranged from 0.64 to 1.28 (Table 1), implying further evidence of less crustal contamination. Only one sample from the rhyolite field has 1.72 ratio value due to it's crustal contamination.

$\mathrm{The} \mathrm{Eu} / \mathrm{Eu}^{*}$ ratio of most samples are less than one (Table 1) wich further proves the rocks to have little crustal contamination and the source to be asthenospheric mantle. From the REE spider diagram its clearly visible that $\mathrm{Eu}$ is developing a little trough wich is due to small contaminations.

\section{Conclusion}

The study area is covered by rocks units such as aphanitic basalt, porphyritic basalt, vesicular basalt, rhyolite and dolerite. Mineralogically, most of the samples in the study area are mafic in nature containing minerals like olivine, pyroxene and plagioclase. The rhyolite outcrop consists of higher proportion of quartz and K-feldspar. Except one sample which lies on the rhyolite field, all the remaining samples lie on basic type of Igneous rocks (Hawwaiite, Mugearite and Basalt fields). All the outcrops in the study area lie on the with in plate tectonic setting.

The rock units in the study area are geochemically enriched in large ion lithophile elements relative to the high field strength elements that could be resulted from the low degree partial melting of the mantle. Except two samples (T1-S3 and T2-S1), all samples are derived from an asthenospheric source and have undergone little to no contamination from the continental crust but rhyolite and dolerite rocks units are strongly affected by crustal contaminations. Europium is developing a little trough wich 
further confims small crustal contaminations.

\section{References}

[1] Bellahsen, N., C. Faccenna, F. Funiciello, J. M. Daniel, and L. Jolivet (2003). Why did Arabia separate from Africa? Insights from 3-D laboratory experiments. Earth Planet. Sci. Lett.

[2] Bonini, M., Corti, G., Innocenti, F., Manetti, P., Mazzarini, F., Abebe, T., Pecskay, Z., 2005. Evolution of the Main Ethiopian Rift in the frame of Afar and Kenya rifts propagation.

[3] Boynton W V (1984). Cosmochemistry of the rare earth elements: meteorite studies. In: Henderson P (eds) Rare Earth Element Geochemistry. Elsevier, Amsterdam, pp 63-114.

[4] Cox K G, Bell J D \& Pankhurst (1979) The Interpretation of Igneous Rocks. Allen \& Unwin, London.

[5] De La Roche H, Leterrier J, Grandclaude P, \& Marchal M (1980). A classification of volcanic and plutonic rocks using R1-R2- diagram and major element analyses - its relationships with current nomenclature. Chem Geol 29: 183-210 doi: 10.1016/0009-2541 (80) 90020-0.

[6] Ebinger, C. J., T. Yemane, D. J. Harding, S. Tesfaye, S. Kelley, and D. C. Rex (2000). Riftmigration and propagation: Linkage of the Ethiopian and Eastern rifts, Africa, Geol. Soc.Am. Bull.

[7] Fitton JG, James D, Kempton PD, Ormerod DS, Leeman WP (1988). The role of lithospheric mantle in the generation of late Cenozoic basic magmas in the western United States. In: Cox KG, Menzies MA, editors. Oceanic and Continental Lithosphere: Similarities and Differences.

[8] Ghebreab, W (1998). Tectonics of the Red Sea region reassessed, Earth Sci. Rev.

[9] Kazmin, V (1975). Explanation of the geological map of Ethiopia. Ethiopian Institute of Geological Surveys, Bull. No. 1.
[10] Leat PT, Thompson RN, Morrison MA, Hendry GL, Dickin AP (1988). Compositionally-diverse Miocene-recent rift related magmatism in northwest Colorado: partial melting, and mixing of mafic magmas from three different asthenospheric and lithospheric mantle sources.

[11] Mojgan S (2008). Petrology, geochemistry and mineral chemistry of extrusive alkalic rocks of the Southern Caspian Sea ophiolite, Northern Alborz, Iran: evidence of alkaline magmatism in Southern Eurasia.

[12] Morley, C. K., W. A. Wescott, D. M. Stone, R. M. Harper, S. T. Wigger, and F. M. Karanja (1992). Tectonic evolution of the northern Kenyan Rift, J. Geol. Soc. London.

[13] Pearce JA (1982). Trace elements characteristics of lavas from destructive plate boundaries. In: Thorpe RS, editor. Andesites. Chichester, UK.

[14] Pearce JA, Norry MJ (1979). Petrogenetic implications of Ti, $\mathrm{Zr}, \mathrm{Y}$ and $\mathrm{Nb}$ variations in volcanic rocks. Contrib Mineral Petrol.

[15] Sun, S. s., Mc Donough, W. F (1989). Chemical and isotopic systematics of oceanic basalts: implications for mantle composition and processes. In: Saunders, In: A.D. (Ed.), Magmatism in the Ocean Basins. Geological Society, London.

[16] Tadiwos Cherinet (2011). Geology and hydrothermal resources in the northern Lake Abaya area (Ethiopia). Journal of African Earth Sciences.

[17] W. Hutchison, T. A. Mather, D. M. Pyle, A. J. Boyce, M. L. M. Gleeson, G. Yirgu, J. D. Blundy, D. J. Ferguson, C. VyeBrown, I. L. Millar, K. W. W. Sims and A. A. Finch (2018). The evolution of magma during continental rifting: new constraints from the isotopic and trace element signatures of silicic magmas from Ethiopian volcanoes, Earth and Planetary Science Letters, 489, 203-218, 2018. (doi: 10.1016/j.epsl.2018.02.027). 